\title{
Balanced Growth using Ontology-based Tantra Framework
}

\author{
Shreekanth Mooror Prabhu*, K. N. Balasubramanya Murthy and Subramanyam Natarajan \\ Department of Computer Science and Engineering, PES University, Banashankari, Bangalore - 560085, Karnataka, \\ India; shreekanthprabhu@pes.edu
}

\begin{abstract}
Indian Economy is one of the fastest growing economies in the world, currently growing at around 7\%. However, India's growth has been highly uneven and lop-sided. Sectors such as services relying on exports have grown far more whereas manufacturing and agriculture have languished. As global trade environment becomes tougher, there is increasing realization that India's domestic economy needs to grow lot more. In this context, balanced growth theory proposed by Ragnar Nurkse and many other Economists in 1950s is worth revisiting. Nurkse called for unleashing growth across different sectors of domestic economy simultaneously. Nurkse identified productivity as key determinant of market size and considered the poor as participants in the growth process than as mere beneficiaries. Even though balanced growth model is an ideal to aspire for, there are very few success stories which laid a clear roadmap to achieve it. Further, we need to reimagine the balanced growth model for today's context to take into consideration newer challenges and opportunities compared to 1950s. In addition, the role of the Government needs to be recalibrated to be a catalyst in market economy in contrast to planned economies. To accomplish this complex task, we need an information framework that has an ecosystem approach and looks at society holistically. We propose the use of Ontology-based Tantra Social Information Management Framework to steer India towards the balanced growth ideal. This paper contains the description of Tantra Framework and our approach to realize balanced growth using Tantra Framework.
\end{abstract}

Keywords: Balanced Growth, Balanced Scorecard, External Economy, Ontology, Zachman Framework

\section{Introduction}

Poverty and inequality have persisted in India in spite of reasonable economic progress. Angus Deaton who extensively studied poverty in India by analysing consumption patterns said "India has been hugely successful in building a better life for many. But there are also terrible dangers of inequality, if those who have escaped from destitution use their wealth to block those who are still imprisoned by it" (The Wire, 2015). He illustrated his point by comparing how escape of some prisoners makes the life of those who stay back harder. Chancel and Piketty (2017) have studied inequality in India extensively. One of the reasons for inequalities is imbalance in real incomes among people, professions and sectors of economy.
Different countries have taken different approaches to achieve economic growth. Majority of success stories revolve around export-led growth. In contrast, Ragnar Nurkse Estonian international economist developed balanced growth theory (Nurkse, 1953; Nurkse, 1961) in the 1950s, which particularly focused on growing domestic economy of underdeveloped countries. Here growth is achieved by growing domestic markets across complementary sectors with a big push. He considered productivity as key determinant for market size in developing countries. This model is worth revisiting, especially for India which has large domestic economy and yet has low per-capita income. We probably need balanced trade along with balanced growth, to grow the economy in today's world that is far too globalized compared to when balanced growth model was proposed. We also need 
to reimagine the balanced growth model to suit today's context. The balanced growth theory however has been challenged by unbalanced growth theory propounded by Hirschman (1958). Neo-classical economic theory that advocates the combination of labour, capital and technology is the most dominant now.

To arrive at the right model for growth, we need an approach that draws on economics, sociology and computer science due to the following reasons:

- Traditional economic analysis looks at society either with macro or micro perspective. In reality much of the economic life takes place in the continuum between the two.

- Sociology traditionally looks at smaller groups where data collection and analysis can be managed and behaviour can be studied. But today social interactions span all over the globe in a digital and virtual manner, which need newer approaches.

- Today's technologies make it easy to manage large amounts of data. The computer platforms are becoming increasingly social where people provide feedback, share knowledge, express opinions, provide suggestions for policy and get influenced by their communities. The social dimension has overtaken the technology dimension.

In this paper we look at applying balanced growth theory to Indian Economy with the help of ontology-based Tantra Framework. Tantra Framework is conceptualized to manage the entire governance and societal information in a comprehensive and holistic manner. Tantra Framework captures information on people, addresses and locations, assets and attributes, events, processes and objectives as well as relationships and relators. Tantra Framework interoperates with balanced scorecard model to set goals, theory of change framework to design interventions and theory of separations to assess the impact of Governance on people.

The framework approach is particularly important to India now, as Indian economy is in the third stage of evolution, after embracing socialism in early decades followed by liberalization in later decades. Currently the challenges as well as opportunities are at the level of ecosystem and only state is in a unique position to catalyse change. Tantra Framework is particularly suited for that.

A key contribution of this paper is to bring balanced growth theory which has confounded economic analysts back into discourse. We found balanced growth theory to be particularly striking in the sense that it looks at poor as participants in the growth process than as mere beneficiaries. We make a case that with right information framework and methodology, balanced growth ideal can indeed be realized.

Rest of the paper is organized as follows. The Section 2, Balanced growth and other Development Theories, does a review of theories of development economics. The Section 3 , Reimagining Balanced Growth in Indian Context, covers how balanced growth theory should be applied in Indian context. The Section 4 describes Tantra Good Governance Framework. The Section 5, covers how to realise Balanced Growth using Tantra Framework. The Section 6, Conclusions, concludes the paper.

\section{Balanced Growth and other Development Theories}

A recent article on development economics in Investopedia (2018) examined different development theories including mercantilisms of European powers which thrived by exploiting colonies, linear stages growth model that was used to rebuild the European countries by public investment in industrialization and economic nationalism that disallowed free flow of capital, goods and labour outside national boundaries. After 1950s, the structural change theory (Economics Online, Structural Change Theory) became popular that included 2-sector Model proposed by Lewis (1955) and 3-Sector Model proposed (Clark, 1940; Fisher, 1939) that included Agriculture, Industry and Services. As more and more colonies became independent, the dependency theory that emphasized the dependence of developing countries (periphery countries) over developed countries (core countries) and asymmetric relationship between them came into discourse. This led many countries to go for closed economies which made matters worse. The neoclassical growth theory suggested use of technology in combination with labour and capital to create new waves of growth. Over the last two centuries, the source of competitive advantage shifted from labour to capital to technology to knowledge. However, the imbalance within economies has persisted.

The advocates of balanced growth stressed that, for an economy to grow, it needed all sectors to grow to support each other. In developed countries entrepreneurs played a key role in developing complementary sectors to unleash economic growth. In developing countries, a big push might be needed by the government to help the economy grow in a balanced way; e.g., ensuring that farming remains developed even when experiencing a manufacturing boom. 
First to put forward the theory of balanced growth (Fisher, 1939 \& Economics Discussion..) was endorsed by Rodan (1943) and developed further by Nurkse (1953), Scitovsky (1954) and Lewis (1955). Lewis emphasized the importance of need for all sectors of economy to grow simultaneously and that domestic sector must grow in balance with the export sector. He maintained that if these sectors are simultaneously developed, the relative prices among them can be maintained. Kindleberger (1958) in his paper maintained that "balanced growth implies that investment takes place simultaneously in all sectors or industries at once". "However, the most widely discussed and accepted meaning of balanced growth is that there should be simultaneous and harmonious development of different sectors of the economy, so as to make available a ready market for the products of different sectors. Thus, balanced growth is not a static term, but it refers to its dynamism".

Nurkse studied the problem of vicious cycle of poverty. He found that low productivity affected both demand and supply cycles. He recognized the need to expand markets to induce investment. "One way the Governments can get around this obstacle is to put more money in the hands of people, but that is inflationary and not sustainable. Other way is to reduce prices to expand markets. This needs to be accompanied with increasing productivity which in turn can increase real incomes of people. So, from a vicious cycle we can move to a virtuous cycle". He characterized the virtuous cycle thus. "Increase in productivity- $>$ Increase in flow of goods and services into Economy->Consumption Rises->Size of Market increases->Inducement to invest for firms-> Economic Growth and development".

The doctrine of balanced growth requires the balance of three types (Table 1).

Table 1. Type of balances in balanced growth theory

\begin{tabular}{|l|l|}
\hline supply-side balance & $\begin{array}{l}\text { In underdeveloped countries, low } \\
\text { Income->low Savings->low } \\
\text { Investment->low capital forma- } \\
\text { tion->low productivity->low } \\
\text { income. To give impetus to entre- } \\
\text { preneurs to invest, set up several } \\
\text { industries simultaneously. }\end{array}$ \\
\hline $\begin{array}{l}\text { demand-side bal- } \\
\text { ance }\end{array}$ & $\begin{array}{l}\text { In the underdeveloped countries, } \\
\text { Low Income } \rightarrow \text { Low Purchasing } \\
\text { Power } \rightarrow \text { Low Investment } \rightarrow \text { Low } \\
\text { Productivity-> Low Income. The } \\
\text { concept of balanced growth from } \\
\text { the demand side is that several } \\
\text { industries should be developed } \\
\text { simultaneously }\end{array}$ \\
\hline
\end{tabular}

\begin{tabular}{|l|l|}
\hline sectoral balance & $\begin{array}{l}\text { Sectoral balance means economic } \\
\text { development of all the sectors } \\
\text { in an economy. For example, } \\
\text { expansion of industrial sector will } \\
\text { raise the demand for raw material } \\
\text { which will only be supplied by } \\
\text { expanding of agricultural sector. }\end{array}$ \\
\hline
\end{tabular}

There are caveats to Nurkse's theory. There could be overproduction and glut in the market that may depress prices. This happens typically in agriculture sector in India where some years there are shortages and other years there is glut. Another caveat is easy availability of foreign capital. The developing countries can easily access foreign capital by opening up markets. However certain already well-performing sectors and regions tend to attract foreign capital. Hence, balanced growth theory continues to be relevant.

Nurkse recognized the importance of innovationbased entrepreneurship, when he referred to Schumpeter's theory of economic development, where rapid growth was achieved through the action of individual entrepreneurs creating recurrent waves of industrial progress. He assumed that developing countries may not have the wherewithal for innovation and entrepreneurship, which however is no longer true. Nurkse emphasized that "Innovation in one industry can create a wave that impacts many others. The rate at which one industry grows is inevitably conditioned by the rate at which other industries grow. Any investment in isolation may seem to have dismal returns". As far as Nurkse is concerned, whether balanced growth happens due to entrepreneurs or with public investment, the nature of solution remains the same.

In current age the Government's role may be more as a catalyst to promote simultaneous investments in multiple sectors. Our belief is that Government has an ecosystem level role to work with private businesses to achieve the balanced growth objective.

When an industry produces a product of higher quality at lower cost, it in turn can trigger growth in another industry by making it possible for it to operate with greater efficiency. For example, efficient transportation industry can boost tourism. This notion is referred to as "external economy". An external economy may be created in a different country and can help balance the trade.

Sheahan (1958) did a critique on balanced growth theory and argued that resources have to be directed to those sectors that can use them more efficiently and the balancing should be about coordinating investments internationally rather than domestically.

In contrast, unbalanced growth theory, associated with the German political economist Albert Hirschman (1958), 
suggests that "overall growth is faster when it is unbalanced. The role of government should be to help support those industries with the strongest linkages to the growth industries or strategically selected industries".

Bhatt (1964) contended that balanced and unbalanced growth strategies are complementary to each other. $\mathrm{He}$ looked at unbalanced growth as a motivator to economy to widen its horizon with respect to growth potentialities, which naturally must focus on specific sectors.

\section{Reimagining Balanced Growth in Indian Context}

Between 2008 and 2011, India's GDP grew between 8 to $10 \%$. Afterwards it dipped to low numbers in 2013 and then has remained largely range-bound between 6 and $8 \%$ shown in Figure 1.

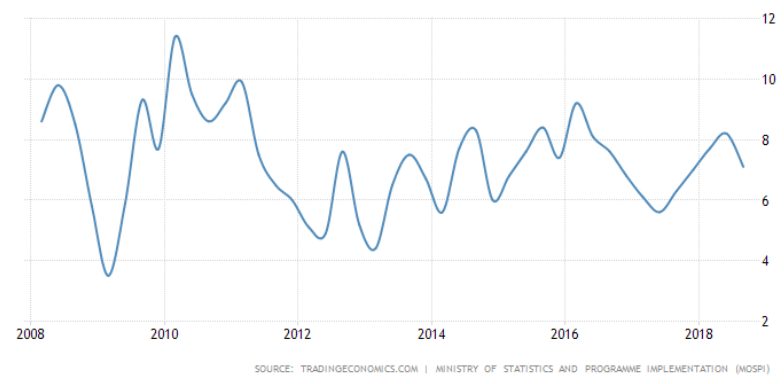

Figure 1. GDP growth rate of Indian economy.

During 2008-2011, there was high GDP growth due to huge investment in private and public sectors. Lot of this investment was done using reckless lending with excessive optimism. The due diligence on profitability was not adequate. As a result, Indian banks are saddled with huge amount of bad loans. After 2014, Government has been fiscally conservative and managed to keep inflation low and macros stable. There have been many administrative reforms including GST leading to India getting high rank on ease of doing business by World Bank. However private investment is lagging. India did attract record level of Foreign Direct Investment (FDI) in the last few years; but nor adequate to compensate slow-down. Balakrishnan (2018) in an article in The Hindu (Smith, 1776) makes a strong case for reviving private investment, while emphasizing its dependence on anticipated profitability. He wrote "Arguably, investment is another, mainly private investment, for governments can always raise their capital outlay ignoring the calculus of profitability. For a private investor, on the other hand, financial commitments are based closely on anticipated profit". Anticipated profit in turn depends on anticipated vigour in the economy.
Secondly there has been significant distress in agriculture sector not only in drought years but even when production of crops was high as farmers suffered due to depressed prices. The third issue is increasing protectionism in the world and India's inability to expand exports or reduce imports. Here again there is need to develop domestic markets.

India is now considered the fastest growing economy in the world. However, India faces many challenges. Firstly, India needs to grow at $10 \%$ rate for many years to substantially increase per-capita income. Secondly the trickle-down theory where high growth is supposed to benefit masses has not operated optimally. Many times, growth is jobless or has resulted in huge inequalities. Thirdly global trade is increasingly competitive, and India is a late-comer. Considering all these aspects, there is belated realization in India to substantially expand the domestic economy. In this context, we believe balanced growth theory is particularly relevant to India of today.

\subsection{Motivating Factors to Apply Balanced Growth Theory in Indian Context}

The following factors make a strong case to consider balanced growth theory in Indian context:

- The Government can act as a catalyst in this drive.

- India gave precedence to manufacturing over Agriculture in the first two decades after independence. Then a crisis led to refocusing on Agriculture in the form of green revolution. There are disparities in income between these sectors and in general between domestic and tradable sectors. India continues to have problem of under-development in many districts and among large sections of society.

- India has had some success in higher education and IT sector that acted as complementary to each other leading to growth of both sectors. IT employees with higher wages made growth of higher education sector more viable.

- India has a large aspirational population. However, this alone will not result in big markets and the real incomes of people should rise and awareness and appetite for differentiated and niche products also should rise. This can be corrected through balanced growth across sectors.

- The IT outsourcing industry in India has enhanced operating efficiencies in the developed world. India can create more such 'external' economies in developed and developing countries. 


\subsection{Limitations to Application of Balanced Growth Theory}

The limitations to application of balanced growth theory to Indian context are as follows:

1. Experience in India has shown that mere increase in productivity and consequent increase in production does not help improve the lot of people.

Secondly even if high productivity leads to high profitability at the level of a firm or employer, it does not necessarily mean high wages to all people. Over the years, export led sectors and some domestic sectors have far higher per-capita income compared to other domestic sectors. The sectoral imbalance has led to high degree of urbanization with poor standard of living. Even if domestic economy is balanced, if the country has a weak currency then people may be particularly vulnerable to price increases in imported items such as crude oil. Weak currency can also come in the way of expanding consumer markets with greater depth and differentiation. Even when a country has a strong currency (the way India had many decades back), if the profits/wealth disproportionately accrues to small elite, it will not be beneficial to people at large.

\subsection{Reimagining Balanced Growth for the Present}

Balanced Growth theory was product of a different time where the developing countries had difficulty expanding markets on their own or in attracting foreign investment. On top of that countries such as India chose to have a closed economy focused on import substitution. Indian economy has opened up and imports are allowed freely. On supply side, India has significant capability to achieve high levels of production whether it is in agriculture or manufacturing. , India has a much higher capacity for innovation and entrepreneurship now. Hence, we need to reimagine the balanced growth model for contemporary milieu.

\subsection{Investment Balance}

In India, there is underinvestment in agriculture and manufacturing. The public investment should be balanced across sectors. The policy framework should facilitate the growth of all sectors.

\subsection{Productivity Balance}

Generally, focus on improving productivity is higher in newer sectors such as high-tech. There needs to be conscious effort to boost productivity in all sectors whether agriculture, manufacturing or services. In addition, lot of land and capital is locked up in unproductive ventures. Finally, supportive environment requires better infrastructure, transportation, logistics and governance. Figure 2 depicts different facets of productivity. Success story of China to become a global manufacturing hub owes a lot to achieving high productivity systemically.

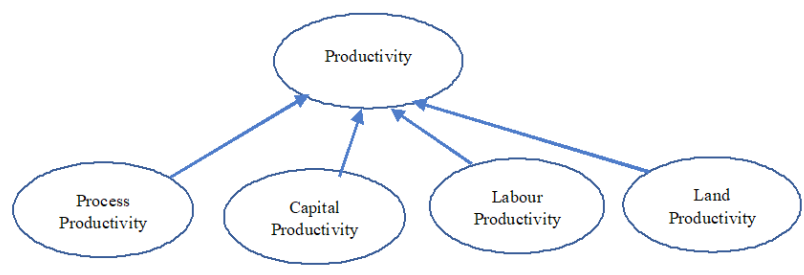

Figure 2. Different facets of Productivity.

\subsection{Innovation Balance}

In India people have a selective approach to innovation, compared to developed countries that use it in all walks of life. India needs to boost innovation across sectors.

\subsection{Sectoral Balance}

We need to reimagine the sectoral balance to be competitive with other nations. This needs better exploitation of complementarities between sectors. We propose that India move from current 3 -sector model of economy consisting of agriculture, manufacturing and services to a 5-sector model. Here the five sectors are agriculture, KnowledgeDesign-Innovation (KDI), manufacturing, trade and services. In this model, agriculture and manufacturing are focused on production and services are focused on fulfilment. The knowledge-design-innovation sector can encourage intellectual and creative pursuits. With the help of an information framework, we can track deployment of people, their productivity as well as innovation quotient across sectors. We can monitor investment distribution and contribution to GDP based on 5-sector model. The KDI sector can help increase the productivity and innovation across all sectors. Figure 3 illustrates role of different sectors in 'value creation to value capture' process. 


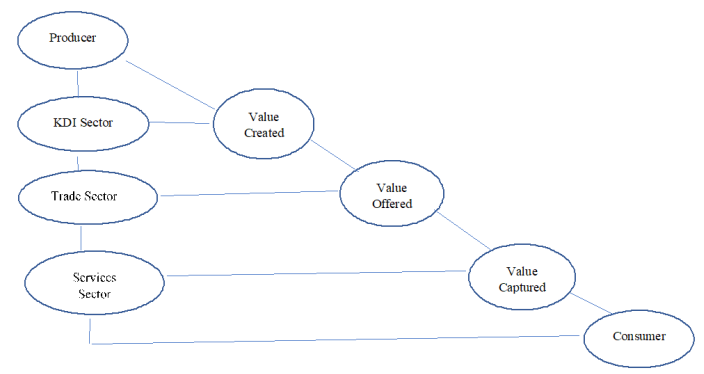

Figure 3. Role of different sectors in value chain.

Sectoral balance also can be thought in terms of harmonizing Public, Private, Informal and Social sectors. Custom products/services are another area India has a natural advantage (Debroy, 2018).

\subsection{Market Balance}

Sectors such as agriculture face vagaries of weather. Other sectors also face business cycles. Using an information framework, it can become easier to predict and monitor demand and plan the supply and distribution strategy in a fine-grained manner. Figure 4 illustrates the Market Network. Here supply and demand may flow through the whole network or parts of it. If each of these entities is modelled and networked, we can measure demand across the network, identify demand hot-spots and supply bottlenecks. In summary an information framework can help achieve market equilibrium and achieve optimal outcomes to market participants.

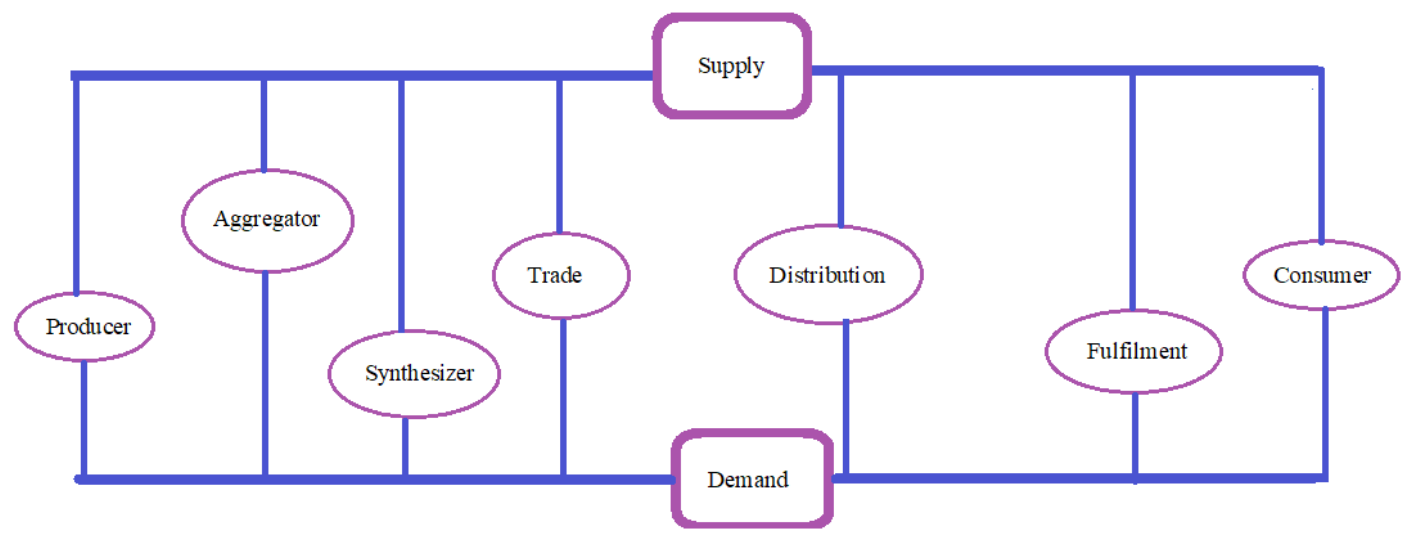

Figure 4. Market network.

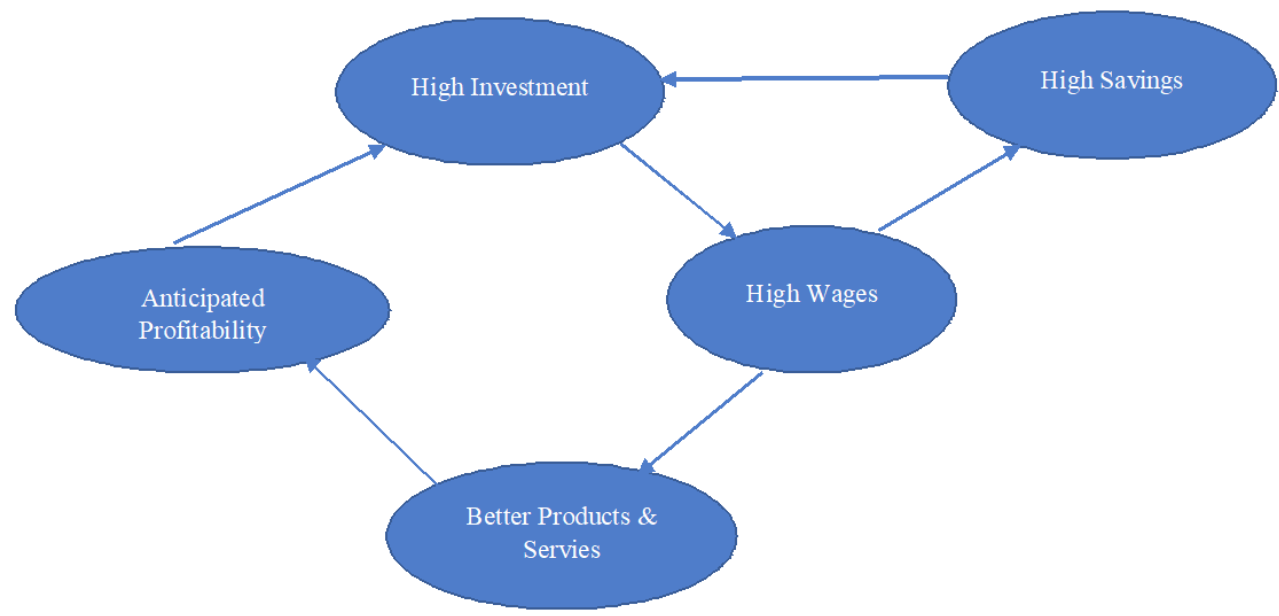

Figure 5. Profitability virtuous cycle. 


\subsection{Profit balance}

The investors invest primarily based on anticipated profitability. Profitability can initiate a new virtuous cycle: Anticipated Profitability -> high investment $->$ high wages -> better products and services -> higher profitability. Here the assumption is that ability to give higher wages can result in attracting better products that can command better pricing. Another virtuous cycle it can unleash is high investment -> high wages -> high savings -> high investment. Figure 5 depicts these virtuous cycles. In India certain sectors such as agriculture end up having lower profitability thus blocking further investment. Then there are sun-rise sectors such as renewable energy, telecom, e-commerce and civil aviation that end up making losses due to price-wars and aggressive cost-cutting/discounting. It is a matter of time investment declines in these sectors. Then there are also core sectors and infrastructures which have to make do with lower profits due to high over-heads and low productivity. Only if profits are balanced across sectors, markets can grow in a sustainable manner. The profitability criteria have become all the more important in India as banks are no longer lending liberally. Lot of investment was done earlier without due regard to profitability. In many cases there is flight of capital overseas using illegal means. All these issues have impacted the value of Indian currency, in turn affecting purchasing power.

\subsection{Wage Balance}

Despite firms doing well, wages for large sections of people remain low, keeping them out of consumer markets. In addition, there may be high supply of labour and the labour market may dictate wages than sectoral profitability. Wage/income imbalances also manifest due to disparities within sectors. In higher education sector pays of teachers may increase only nominally when the fees paid by students increase in leaps. A farmer may get only Rs 2 for produce when consumer pays Rs 20 for the same. Jaffrelot (2018) wrote about the issues of landless labourers (or peasants) getting lost in the narrative on agriculture distress. He says the landowning farmers seldom bothered about labourers. A fine-grained analysis with a social information framework can help address wage paradox. Income disparities exist due to asymmetry of bargaining power. Here understanding the structure and nature of society is important. India has huge number of small enterprises and many of them are viable only with self-employment. Manish Sabharwal (2018a \& 2018b) has been vocal that India's real problem is low wages and not lack of jobs. His solution to the problem is to formalize jobs and companies as much as possible. Acemoglu (2012) differentiated between extractive and inclusive philosophy of colonizing powers in his book "Why nations fail". This applies to businesses and industry sectors as well. The inclusive businesses prosper by sharing their wealth with employees.

\subsection{Opportunity Balance}

Even when markets grow, the unemployment levels may remain high due to skill, education, gender, age and cultural barriers. With some re-training, repurposing or reconfiguring jobs and flexibility on part of employers, employment levels can be significantly increased. Lack of adequate jobs is part of prevailing political discourse in India. There needs to be balanced access to job opportunities, without which even wages may experience huge skew. Another way to look at opportunity balance is locating more of the economy in social sector. In the social sector, self-employed people and small businesses can deal directly with end-users over internet or through an intermediary platform. These may be e-commerce platforms or intermediaries such as Uber and Ola, where the platforms can help increase the opportunities significantly. They may also give flexible work options.

\section{Ontology-Based Tantra Framework}

The name Tantra Framework is chosen to reflect enormous connectivity of information through the framework. Etymologically in Sanskrit "tantram", literally means "loom, warp," hence, figuratively, "groundwork, system, doctrine".

Tantra Framework extends Zachman (2003, 2007) by adding three additional columns namely relators, relationships and separations. The relationship column is used to represent any relationship which may correspond to a data-map or structured map, between framework columns. A relator column is added to represent any entity/concept that is integral part of any relationship. Relator column is inspired by Unified Foundational Ontology (Santos Jr, et al. 2013). Separations are used to represent lack of relationship or the level of difficulty to access the relationship. The idea of separations is inspired by the Bartels' Theory of Separations (Bartels, 1968). The Table 2 gives the view of Tantra Framework.

The aspects of Tantra Framework can be used to expresses social information as follows: 
- People/Communities/Businesses (Who).

- Places/Addresses/Locations/Zones (Where).

- Assets/Attributes (What).

- Events (When).

- Processes (for enrolment, intervention) (How).

- Metrics to measure development (Why).

- Relators (enable relationships).

- Relationships (between aspects). and

- Separations (express lack of or difficulty of establishing a relationship).

\subsection{Tantra Good Governance Framework}

In Tantra Frameworkas in Zachman Framework everyaspect goes through the process of reification. Table 3 describes how People Domain is reified. Similarly Addresses and Zones can be reified under 'Where' aspect and Assets under 'What' aspect. Table 4 covers income perspective. Loans can be similarly tracked to get complete financial profile of people. Table 5 covers the reification of relationships and relators and Table 6 covers separations with access to
Formal Credit. Table 7 covers metrics that are important to economy. Similarly, events that occur during lifetime of a person can be reified and given a unique ID. These include birth, attaining maturity, migration, enrolment, emigration, immigration and death. The processes can similarly be covered. The objectives are covered in the next section. Tantra Framework is implemented using Neo4j graph database which gives it power of visualization.

Tantra Framework can be a great resource to Social Scientists supporting research methods. It is particularly suited to grounded theory method. According to Martin and Turner (1986) grounded theory is "an inductive, theory discovery methodology that allows the researcher to develop a theoretical account of the general features of a topic while simultaneously grounding the account in empirical observations or data". The grounded theory suggests that there should be a continuous interplay between data collection and analysis. Myers (1997) has comprehensively covered different social science research methods in the context of information systems.

Table 2. Tantra framework

\begin{tabular}{|c|c|c|c|c|c|c|c|c|c|}
\hline \multirow{2}{*}{ Perspectives } & \multicolumn{9}{|c|}{ Aspects } \\
\hline & Who & Where & What & When & How & Why & Relationships & Relators & Separations \\
\hline $\begin{array}{l}\text { Contextual } \\
\text { (Named and } \\
\text { Scoped) }\end{array}$ & & & & & & & & & \\
\hline $\begin{array}{l}\text { Conceptual } \\
\text { (Defined) }\end{array}$ & & & & & & & & & \\
\hline $\begin{array}{l}\text { Logically } \\
\text { Designed }\end{array}$ & & & & & & & & & \\
\hline $\begin{array}{l}\text { Physically } \\
\text { Configured } \\
\text { (Schema) }\end{array}$ & & & & & & & & & \\
\hline $\begin{array}{l}\text { Detailed/In- } \\
\text { stan-tiated) }\end{array}$ & & & & & & & & & \\
\hline
\end{tabular}

Tantra Framework can be positioned as Knowledge Management Framework (Prabhu, Murthy \& Subramanyam, 2018a). Tantra Framework is applied to varied application scenarios such as transforming India's electoral democracy (Prabhu, Murthy \& Subramanyam, 2019a) intelligent social banking (Prabhu, Murthy \& Subramanyam, 2019b) assisting in revenue capture (Prabhu, Murthy \& Subramanyam, 2018b) and realizing balanced development (Prabhu, Murthy \& Subramanyam, 2019c). In (Prabhu, Murthy \& Subramanyam, 2019d) entropy was proposed as an instrument of validation for Tantra Framework.

Tantra Framework as defined above can be converted into a normative framework by interoperating with models that can help achieve Good Governance (Figure 6). 
Here Goals can be set using Balanced Scorecard Framework (Kaplan, 2010 \& Tarafdar \& Singh, 2011) and interventions can be modelled and managed through Theory of Change Framework (Weiss, 1995). The Separations can be expressed by drawing on Bartels' Theory of Separations (Bartels, 1968).

\begin{tabular}{|l|}
\hline Goals (Balanced Scorecard) \\
Interventions (Theory of Change) \\
Separations (Disconnects) \\
Social Information Space \\
\hline
\end{tabular}

Figure 6. Tantra good governance framework.

Table 3. Reification of people domain

\begin{tabular}{|l|l|l|l|l|l|}
\hline \multicolumn{1}{|c|}{ Pers-pective } & \multicolumn{1}{|c|}{ All people } & \multicolumn{1}{c|}{ Citizens } & \multicolumn{1}{c|}{ Residents } & \multicolumn{1}{c|}{ Resident Aliens } & \multicolumn{1}{c|}{ Resident Citizens } \\
\hline $\begin{array}{l}\text { Named (Iden- } \\
\text { tified \& Con- } \\
\text { textualized) }\end{array}$ & $\begin{array}{l}\text { All the people } \\
\text { known and to } \\
\text { be known to the } \\
\text { framework. }\end{array}$ & $\begin{array}{l}\text { People who t are } \\
\text { citizens }\end{array}$ & $\begin{array}{l}\text { People who are } \\
\text { residents }\end{array}$ & $\begin{array}{l}\text { People who are } \\
\text { resident but alien }\end{array}$ & Resident Citizens \\
\hline $\begin{array}{l}\text { Defined } \\
\text { (Conceptually } \\
\text { Structured) }\end{array}$ & $\begin{array}{l}\text { What makes } \\
\text { one a member } \\
\text { of this domain/ } \\
\text { role }\end{array}$ & $\begin{array}{l}\text { What makes one } \\
\text { a member of this } \\
\text { domain/role }\end{array}$ & $\begin{array}{l}\text { What makes one } \\
\text { a member of this } \\
\text { domain/role }\end{array}$ & $\begin{array}{l}\text { What makes one } \\
\text { a member of this } \\
\text { domain/role }\end{array}$ & $\begin{array}{l}\text { What makes one } \\
\text { a member of this } \\
\text { domain/role }\end{array}$ \\
\hline $\begin{array}{l}\text { Logically De- } \\
\text { signed }\end{array}$ & $\begin{array}{l}\text { Related attri- } \\
\text { butes that map } \\
\text { to other aspects }\end{array}$ & $\begin{array}{l}\text { Related attributes } \\
\text { that map to other } \\
\text { aspects }\end{array}$ & $\begin{array}{l}\text { Related attributes } \\
\text { that map to other } \\
\text { aspects }\end{array}$ & $\begin{array}{l}\text { Related attributes } \\
\text { that map to other } \\
\text { aspects }\end{array}$ & $\begin{array}{l}\text { Related attributes } \\
\text { that map to other } \\
\text { aspects }\end{array}$ \\
\hline Configured & $\begin{array}{l}\text { Representation } \\
\text { in Graph data- } \\
\text { base as nodes } \\
\text { and edges }\end{array}$ & $\begin{array}{l}\text { Representation in } \\
\text { Graph database as } \\
\text { nodes and edges }\end{array}$ & $\begin{array}{l}\text { Representation in } \\
\text { Graph database as } \\
\text { nodes and edges }\end{array}$ & $\begin{array}{l}\text { Representation in } \\
\text { Graph database as } \\
\text { nodes and edges }\end{array}$ & $\begin{array}{l}\text { Representation in } \\
\text { Graph database as } \\
\text { nodes and edges }\end{array}$ \\
\hline Instantiated & $\begin{array}{l}\text { Instantiate with } \\
\text { unique ID }\end{array}$ & $\begin{array}{l}\text { Instantiate with } \\
\text { unique ID }\end{array}$ & $\begin{array}{l}\text { Instantiate with } \\
\text { unique ID }\end{array}$ & $\begin{array}{l}\text { Instantiate with } \\
\text { unique ID }\end{array}$ & $\begin{array}{l}\text { Instantiate with } \\
\text { unique ID }\end{array}$ \\
\hline
\end{tabular}

Table 4. Reification of incomes

\begin{tabular}{|l|l|l|l|l|}
\hline & \multicolumn{1}{|c|}{ Income Salary } & \multicolumn{1}{c|}{ Business } & \multicolumn{1}{c|}{ Agricultural } & \multicolumn{1}{c|}{ Other } \\
\hline Named & Name of the income & $\begin{array}{l}\text { Name of the } \\
\text { income }\end{array}$ & Name of the income & Name of the income \\
\hline Defined & Concept of income & $\begin{array}{l}\text { Concept of in- } \\
\text { come }\end{array}$ & Concept of income & Concept of income \\
\hline $\begin{array}{l}\text { Logically De- } \\
\text { signed }\end{array}$ & Related Attributes & Related Attributes & Related Attributes & Related Attributes \\
\hline Configured & Schema & Schema & Schema & Schema \\
\hline Instantiated & $\begin{array}{l}\text { Instantiate with unique } \\
\text { ID }\end{array}$ & $\begin{array}{l}\text { Instantiate with } \\
\text { unique ID }\end{array}$ & $\begin{array}{l}\text { Instantiate with } \\
\text { unique ID }\end{array}$ & Instantiate with unique ID \\
\hline
\end{tabular}


Table 5. Relationships and relators

\begin{tabular}{|l|l|l|l|l|}
\hline & \multicolumn{2}{|c|}{ Banking (Savings) } & \multicolumn{2}{c|}{ Loans } \\
\hline $\begin{array}{l}\text { Named (Identi- } \\
\text { fied) }\end{array}$ & $\begin{array}{l}\text { Name of the idea and } \\
\text { context for relationship } \\
\text { (Savings account) }\end{array}$ & $\begin{array}{l}\text { Name of the idea and context } \\
\text { for relator (Bank) }\end{array}$ & $\begin{array}{l}\text { Name of } \\
\text { the idea and } \\
\text { context for } \\
\text { relation-ship }\end{array}$ & $\begin{array}{l}\text { Name of the idea and } \\
\text { context for relator } \\
\text { (Housing Finance } \\
\text { Company) }\end{array}$ \\
\hline $\begin{array}{l}\text { Defined (Con- } \\
\text { cep-tually Struc- } \\
\text { tured) }\end{array}$ & $\begin{array}{l}\text { Concept of Relation- } \\
\text { ship }\end{array}$ & Concept of Role of relator & $\begin{array}{l}\text { Concept of } \\
\text { Relation-ship }\end{array}$ & $\begin{array}{l}\text { Concept of Role of } \\
\text { relator, }\end{array}$ \\
\hline $\begin{array}{l}\text { Logically De- } \\
\text { signed }\end{array}$ & Related Attributes & Related Attributes & $\begin{array}{l}\text { Related } \\
\text { Attributes }\end{array}$ & Related Attributes \\
\hline $\begin{array}{l}\text { Configured } \\
\text { Instantiated }\end{array}$ & Account No. & Network Schema & $\begin{array}{l}\text { Network } \\
\text { Schema }\end{array}$ & Network Schema \\
\hline
\end{tabular}

Table 6. Separations that come in the way of formal credit

\begin{tabular}{|c|c|c|c|c|c|}
\hline Informational & Capability & Spatial & Temporal & Financial & Social \\
\hline $\begin{array}{l}\text { From borrow- } \\
\text { er's view-point } \\
\text { information on } \\
\text { processes may } \\
\text { be hard to access } \\
\text { and understand. }\end{array}$ & $\begin{array}{l}\text { Capability to } \\
\text { utilize funds may } \\
\text { not be there. For } \\
\text { example, starting } \\
\text { a small business } \\
\text { requires lot more } \\
\text { than mere access } \\
\text { to funds. }\end{array}$ & $\begin{array}{l}\text { Not all bank } \\
\text { branches lend. } \\
\text { Getting a loan } \\
\text { may need multiple } \\
\text { trips to remote } \\
\text { locations }\end{array}$ & $\begin{array}{l}\text { Banks may take } \\
\text { rather long to } \\
\text { disburse loans. } \\
\text { The people may } \\
\text { need to work with } \\
\text { Micro-finance } \\
\text { companies who } \\
\text { may charge higher. }\end{array}$ & $\begin{array}{l}\text { People may not } \\
\text { have access to col- } \\
\text { lateral. Only some } \\
\text { banks may accept } \\
\text { gold as collater- } \\
\text { al. If they pledge } \\
\text { land, they may } \\
\text { lose their source of } \\
\text { livelihood. }\end{array}$ & $\begin{array}{l}\text { Communities } \\
\text { that are not } \\
\text { considered } \\
\text { as trust-wor- } \\
\text { thy end up } \\
\text { getting less } \\
\text { loans. }\end{array}$ \\
\hline
\end{tabular}

\section{Balanced Growth using Tantra Framework}

Balanced Growth theory undoubtedly has great promise. The hypothesis we need to validate is "Balanced growth depends on investment balance, productivity balance, innovation balance, sectoral balance, market balance, profit balance, opportunity balance and wage balance". Tantra Framework can help validate the hypothesis and design interventions. This section describes how we model
Balanced Growth, the strategy we use to realize it and how we validate the Balanced Growth hypotheses.

\subsection{Model}

Table 7 deals with how the social information modelled in order to support the balanced growth case. Tantra Framework captures social information using 9 dimensions. Table 8 details the metrics and measures that need to be modelled under objectives aspect.

Table 7. Modelling balanced growth using Tantra framework

\begin{tabular}{|l|l|}
\hline \multicolumn{1}{|c|}{ Aspect/ Role } & \multicolumn{1}{c|}{ Remarks } \\
\hline Who: People & $\begin{array}{l}\text { People domain is divided into overlapping roles as consumers, producers, intermediar- } \\
\text { ies and labour/workmen/employees. People are associated with professions, businesses, } \\
\text { sectors and social groups based on skills, education, employment status, marital status, } \\
\text { background, age, gender, place of origin, residence and so on. }\end{array}$ \\
\hline
\end{tabular}




\begin{tabular}{|c|c|}
\hline Aspect/ Role & Remarks \\
\hline Who: Businesses & $\begin{array}{l}\text { A business may be in production, trade, distribution, fulfilment or high-tech. A business } \\
\text { is associated with sectors and categorized as domestic, export and so on (again in over- } \\
\text { lapping manner). A business may be Government-owned, private, informal or social. }\end{array}$ \\
\hline Where: Locations, Zones & All geographic locations and zones of different granularity are modelled here. \\
\hline Where: Sector & The sectors and sub-sectors are modelled here \\
\hline When: Events & Events of interest to economy are modelled here \\
\hline When: Periods & Durations of study such as financial year, quarter or seasons are modelled here \\
\hline What: Products \& Services & $\begin{array}{l}\text { The products and services as part of eco-system are modelled here. This may include } \\
\text { plain products or offerings. }\end{array}$ \\
\hline What: Assets & Assets owned by businesses can be tracked here. \\
\hline What: Attributes & $\begin{array}{l}\text { Any attributes of interest pertaining to people, businesses, products or any other aspect } \\
\text { are modelled here. }\end{array}$ \\
\hline How: Process & Intervention processes to arrive at different kinds of balances can be tracked here. \\
\hline Why: Objectives & High level objectives are tracked here by linking to metrics and targets \\
\hline Why: Metrics & Typically, ratio between measures \\
\hline Why: Measures & All measures of interest related to market or society are tracked here. \\
\hline Why: Target & Target required to meet an objective \\
\hline \multicolumn{2}{|l|}{ Relator } \\
\hline Intermediary & Any intermediary such as trader can be considered relator depending on the context \\
\hline Service-provider & KDI sector may be considered a service provider to boost innovation and productivity. \\
\hline \multicolumn{2}{|l|}{ Relationships } \\
\hline Networks & $\begin{array}{l}\text { Supply Networks, Market Networks, Virtuous Cycles and Vicious Cycles can all be rep- } \\
\text { resented as networks. Social Sector can be modelled as a network. }\end{array}$ \\
\hline \multicolumn{2}{|l|}{ Separations } \\
\hline Separations for Businesses & $\begin{array}{l}\text { Financial, Informational, Temporal and Spatial separations in marketing context for } \\
\text { businesses. }\end{array}$ \\
\hline Separations for people & All separations including social and knowledge/capability can be modelled here. \\
\hline
\end{tabular}

Table 8. Measures and metrics for balanced growth case

\begin{tabular}{|l|l|l|l|}
\hline \multicolumn{1}{|c|}{ Economy } & \multicolumn{1}{|c|}{ Sector } & \multicolumn{1}{c|}{ Business/Market } & \multicolumn{1}{c|}{ People } \\
\hline $\begin{array}{l}\text { GDP, external trade, investment, } \\
\text { consumption, savings, per- } \\
\text { capita Income, poverty level, un } \\
\text { unemployment Level, inequality } \\
\text { measures, innovation }\end{array}$ & $\begin{array}{l}\text { GDP, Investment, Produc- } \\
\text { tivity, Income, Profitabili- } \\
\text { ty, innovation }\end{array}$ & $\begin{array}{l}\text { Supply, demand, reve- } \\
\text { nue, profit, innovation }\end{array}$ & $\begin{array}{l}\text { Income, savings, produc- } \\
\text { tivity, innovation, con- } \\
\text { sumption, investment }\end{array}$ \\
\hline
\end{tabular}




\subsection{Strategy}

We can use the following strategy to enable Balanced Growth.

\subsubsection{Have a Process to Assess Metrics Related to Hypotheses and Set up Action Plans to Meet Individual Goals}

Given below are indicative actions to validate hypotheses and realize goals.

- Make assessment of productivity, innovation levels and professionalization. Design appropriate interventions in the form of training programs and other policy actions. Have a process to evaluate the intervention starting from planning stage itself.

- Assess market equilibrium for sectors such as agriculture and develop projection for demand and supply levels.

- Transition to 5-sector model where the sectors work synergistically. Identify investment required in each sector and plan the investment. Promote social sector enabled by internet economy and social platforms.

- Have a model to assess anticipated profitability to guide and encourage investment. Take corrective action for sectors that are not attractive enough. Some actions may be regulatory to avoid price-wars. Others may be supportive. Find avenues for differentiation and creation of new markets.

- Analyse social indicators regarding unemployment, wage and disparities in each sector. Identify groups to target and design interventions to expand opportunities for them. Mobility metrics can be handy here.

\subsubsection{Use Balanced Scorecard Framework to Bring about Change}

The balanced scorecard framework has two guiding principles. An Enterprise (in this case Government) needs to pay attention to all the perspectives in a balanced manner. Secondly paying attention to other perspectives in turn boosts the Financial Performance. Gomes and Liddle (2009) made use of balanced scorecard to create a strategic map that linked perspectives. Same exercise is attempted below in governance scenario (Figure 7). Here we use learning and growth as the foundational perspective, which can boost productivity, engender innovation and inculcate work culture of excellence. This in turn has cascading effect over higher perspectives finally leading to prosperous nation with well-to-do people.

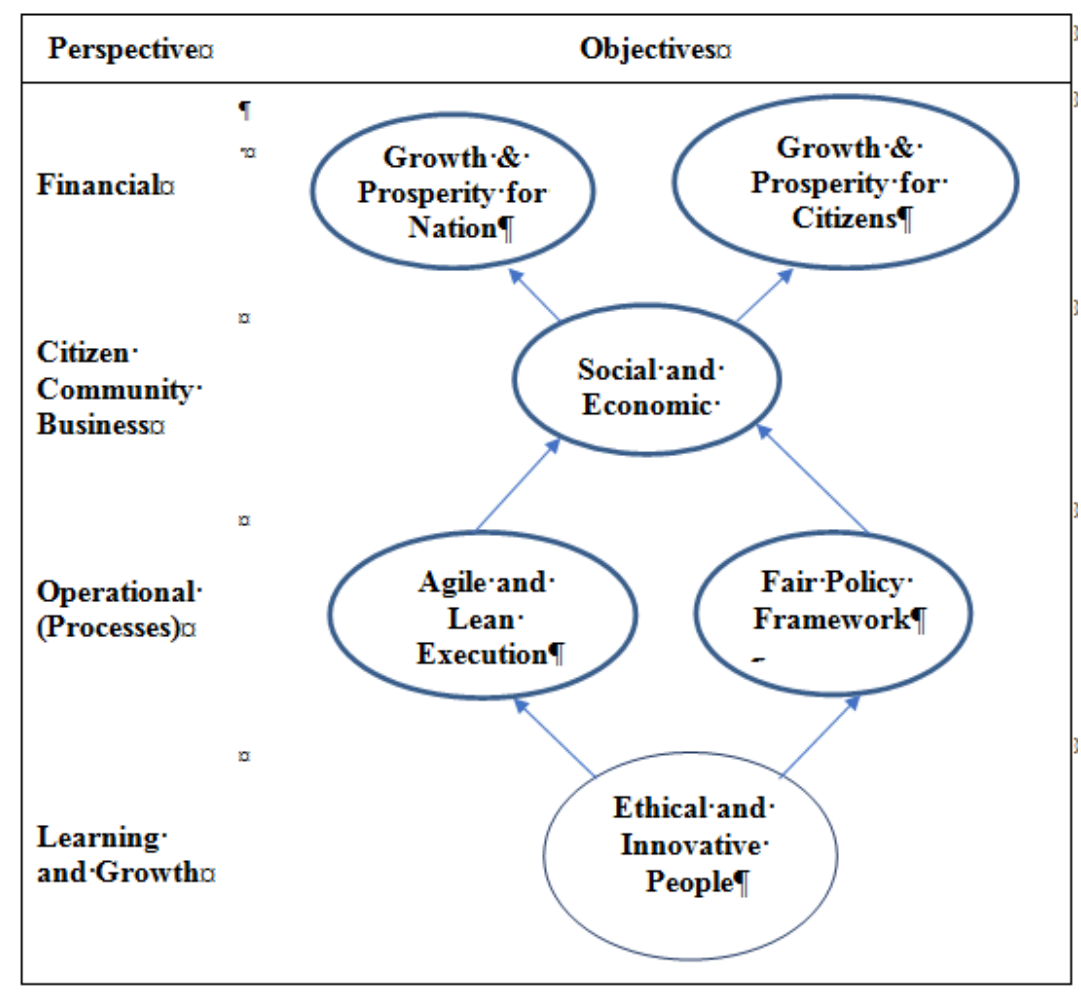

Figure 7. Strategic map of balanced scorecard perspectives in governance scenario. 


\subsubsection{Track Progress using Indices Aligned to Balanced Scorecard Perspectives}

Table 9 gives a list of indices that give a comprehensive view of the economy aligned to balanced scorecard perspectives. The indices defined using financial perspective look at how we get out of resources at disposal, efficiency of tax recoveries, productivity and so on. Along citizen/community/perspective we look at metrics that directly touch the stakeholders. Mobility index measures economic, social and occupational mobility of people.
Using process perspective, we look at whether government policies are fair and equitable in intent and implementation. Then we measure leanness and agility of Governance processes. Finally, using learning and growth we look at adoption of new behaviours and technologies by people. This is followed by measuring social innovation, diversification of economic activities and leverage of networks to grow economy. Finally, ethical perspective focuses on ethical behaviour and strong work ethic. Table 9 details the indices and the method of computation.

Table 9. Balanced scorecard perspectives and Indices

\begin{tabular}{|c|c|c|c|}
\hline \multicolumn{4}{|l|}{ Financial Perspective } \\
\hline Capitalization Index & \multicolumn{2}{|c|}{ Ability to monetize national resources } & $\begin{array}{l}\mathrm{C}(\mathrm{x})=\sum \text { Monetization Rate*Resource Quanti- } \\
\text { ty/ } \sum \text { Input Rate*Resource Quantity }\end{array}$ \\
\hline Competitiveness Index & \multicolumn{2}{|c|}{$\begin{array}{l}\text { As defined and tracked by global insti- } \\
\text { tutions }\end{array}$} & \\
\hline Productivity & \multicolumn{3}{|c|}{ Standard Economic measure } \\
\hline Revenue Capture Index & \multicolumn{2}{|c|}{$\begin{array}{l}\text { Ability to measure extent of revenue } \\
\text { collected } \\
\text { Out of what is due to Government. }\end{array}$} & $\begin{array}{l}\mathrm{R}(\mathrm{x})=\text { Revenue Captures/Revenue Due } \\
\mathrm{D}(\mathrm{x})=\text { Defaulters/Total }\end{array}$ \\
\hline \multicolumn{4}{|c|}{ Citizen/Community/Business Perspective } \\
\hline \multicolumn{2}{|c|}{ Mobility Index } & $\begin{array}{l}\text { Social, Economic and Occupa- } \\
\text { tional Mobility }\end{array}$ & $\begin{array}{l}\mathrm{M}(\mathrm{x})=\text { \# of people experienced Mobility per } \\
\text { thousand people }\end{array}$ \\
\hline \multicolumn{2}{|c|}{$\begin{array}{l}\text { Citizen Satisfaction Index } \\
\text { Community Satisfaction Index } \\
\text { Business Satisfaction Index }\end{array}$} & $\begin{array}{l}\% \text { of inputs, complaints and } \\
\text { suggestions addressed }\end{array}$ & $\begin{array}{l}\text { CSI }=\% \text { of Issues Addressed (with weights)/ } \\
\text { Total number of issues (with weights) }\end{array}$ \\
\hline \multicolumn{4}{|c|}{ Process Perspective } \\
\hline \multicolumn{2}{|l|}{ Fairness Index } & $\begin{array}{l}\text { Ability to deliver benefits, ser- } \\
\text { vices and opportunities fairly } \\
\text { across the society. Fairness } \\
\text { Index can be tuned to measure } \\
\text { whether somebody gets fair } \\
\text { share as per their entitlement } \\
\text { (in place of equal share) }\end{array}$ & $\begin{array}{l}\mathrm{i}^{\text {th }} \text { user gets } \mathrm{x}_{\mathrm{i}} \text { allocation among } \mathrm{n} \text { users, then } \\
\text { fairness index } \\
\mathrm{F}(\mathrm{x})=\sum\left|\mathrm{x}_{\mathrm{i}}\right|^{2} / \mathrm{n} \sum \mathrm{x}_{\mathrm{i}}^{2} \text { for } \mathrm{i}=1 \text { to } \mathrm{n}\end{array}$ \\
\hline \multicolumn{2}{|l|}{ Leanness Index } & $\begin{array}{l}\text { Re-engineer the process to } \\
\text { only essential steps based on } \\
\text { causality }\end{array}$ & $\begin{array}{l}\mathrm{L}(\mathrm{x}) \text { = Diameter of Process Network. Diame- } \\
\text { ter is largest geodesic i.e. largest shortest path }\end{array}$ \\
\hline \multicolumn{2}{|l|}{ Agility Index } & Track the process for timeliness & $\begin{array}{l}\mathrm{A}(\mathrm{x})=\% \text { of process executions that met Ser- } \\
\text { vice Level Criteria } \\
\mathrm{A}(\mathrm{q})=\text { Average Process Execution Time/ Lean } \\
\text { Process Execution Time } \\
\mathrm{A}(\mathrm{p})=\% \text { of paths that can meet SLC/ Total } \\
\text { Paths in process network }\end{array}$ \\
\hline
\end{tabular}




\begin{tabular}{|l|l|l|}
\hline Learning and Growth Perspective & Learning new behaviours & $\begin{array}{l}\text { LG (x)= \# of people who have switched over } \\
\text { to new behaviour per thousand people }\end{array}$ \\
\hline Learning and Growth Index & $\begin{array}{l}\text { Innovation intensity across } \\
\text { society }\end{array}$ & $\begin{array}{l}\text { Social Innovation Index = \# of innovators per } \\
\text { thousand in India }\end{array}$ \\
\hline Diversification Index & $\begin{array}{l}\text { Restructuring of Economy be- } \\
\text { tween traditional and new areas } \\
\text { with potentialities }\end{array}$ & $\begin{array}{l}\text { Div(x) = Investment in Sun-rise areas/Size of } \\
\text { Economy }\end{array}$ \\
\hline Networking Index & $\begin{array}{l}\text { Growth of Economy due to } \\
\text { Internet/peer to peer transac- } \\
\text { tions (uber-like or any internet } \\
\text { discovered relationship) }\end{array}$ & Net(x)= Platform based GDP/Total GDP \\
\hline Ethical Perspective & Proclivity to behave ethically & $\begin{array}{l}\text { E(x)=\# of people are tax compliant per thou- } \\
\text { sand people } \\
\text { E(x)=\# of people who pay back the loans per } \\
\text { thousand people }\end{array}$ \\
\hline Ethical Behaviour Index & Excellence as an ethical value & $\begin{array}{l}\text { Work-Ethic Index(x)= \# of people who excel } \\
\text { per thousand people } \\
\text { E(x)=\# of people who are ethical per thou- } \\
\text { sand people }\end{array}$ \\
\hline Work-ethic Index &
\end{tabular}

\subsection{Validation}

Table 10 explains how the validation of balanced growth hypotheses is done.

Table 10. Validating balanced growth hypotheses

\begin{tabular}{|c|l|l|}
\hline$\#$ & \multicolumn{1}{|c|}{ Hypothesis } & \multicolumn{1}{c|}{ Validation Method } \\
\hline 1. & $\begin{array}{l}\text { Investment } \\
\text { Balance }\end{array}$ & $\begin{array}{l}\text { Tantra Framework can track investment in different sectors and validate if investing in neglect- } \\
\text { ed sectors boosts not only that sector but also the economy as a whole. }\end{array}$ \\
\hline 2. & $\begin{array}{l}\text { Productivity } \\
\text { Balance }\end{array}$ & $\begin{array}{l}\text { Productivity of all sectors should be tracked and gaps found. Interventions designed and } \\
\text { outcomes evaluated to validate the hypothesis. Government in coordination with industry can } \\
\text { have initiatives to improve productivity. This may cover sectoral skills, soft-skills, work-ethic, } \\
\text { better processes, work environment etc. Productivity measurements should include labour, } \\
\text { land, capital, logistics and processes and interventions identified. }\end{array}$ \\
\hline 3. & $\begin{array}{l}\text { Innovation } \\
\text { Balance }\end{array}$ & $\begin{array}{l}\text { Innovation should be encouraged in all sectors not just in emerging sectors. It is suggested } \\
\text { a separate KDI sector for better products and a trade sector to come up with better business } \\
\text { models, and value-added offerings. In addition, we need to look at complementarity in value } \\
\text { engineering across all sectors including services. The outcome of innovation in terms of growth } \\
\text { in economy, profitability or trade balance can be measured. }\end{array}$ \\
\hline 4. & $\begin{array}{l}\text { Sectoral Bal- } \\
\text { ance }\end{array}$ & $\begin{array}{l}\text { Advantage of 5-sector model working in complementary fashion can be validated using growth } \\
\text { metrics. Encourage social sector and support informal sector. }\end{array}$ \\
\hline 5. & $\begin{array}{l}\text { Market Bal- } \\
\text { ance }\end{array}$ & $\begin{array}{l}\text { Demand and supply throughout the market network can be monitored and inputs given to } \\
\text { plan future production. }\end{array}$ \\
\hline
\end{tabular}




\begin{tabular}{|c|l|l|}
\hline$\#$ & Hypothesis & \multicolumn{1}{c|}{ Validation Method } \\
\hline 6. & Profit balance & $\begin{array}{l}\text { Each sector and sub-sector should be analysed so that all can have fair profits. This in turn can } \\
\text { make all sectors grow in balanced manner. }\end{array}$ \\
\hline 7. & Wage-balance & $\begin{array}{l}\text { This needs fine-grained analysis of professions. At limes greater professionalization through } \\
\text { training can deliver higher wages to the workmen. There may be other mind-set related issues } \\
\text { of paying certain professions lowly and certain others highly irrespective of value generated. } \\
\text { Certain wages may be negotiated at group level and there may not be mechanisms to pay high } \\
\text { performers more. }\end{array}$ \\
\hline 8. & $\begin{array}{l}\text { Opportunity } \\
\text { Balance }\end{array}$ & $\begin{array}{l}\text { The growth in employment opportunities can be analysed for sectors, social groups, age } \\
\text { groups, etc. The interventions needed may include matching opportunities, change of mind- } \\
\text { sets, and removal of entry-barriers and review of job qualifications and so on. This should } \\
\text { be looked at from the point of view of using a resource in the best possible manner and fair } \\
\text { monetization. Invigorating social sectors that uses internet economy can play an important role } \\
\text { in opportunity balance. }\end{array}$ \\
\hline
\end{tabular}

\subsection{Operationalizing Balanced Growth Model using Tantra Framework}

Here we envisage that Tantra information framework will operate as part of larger digital governance framework that looks at information at societal and eco-system scale. The whole process needs to be well-governed. Here we use high level ideas from TM Forum's Frameworx (https:// www.tmforum.org/tm-forum-frameworx-2) and conceive Tantra Digital Governance Framework (Figure 8).

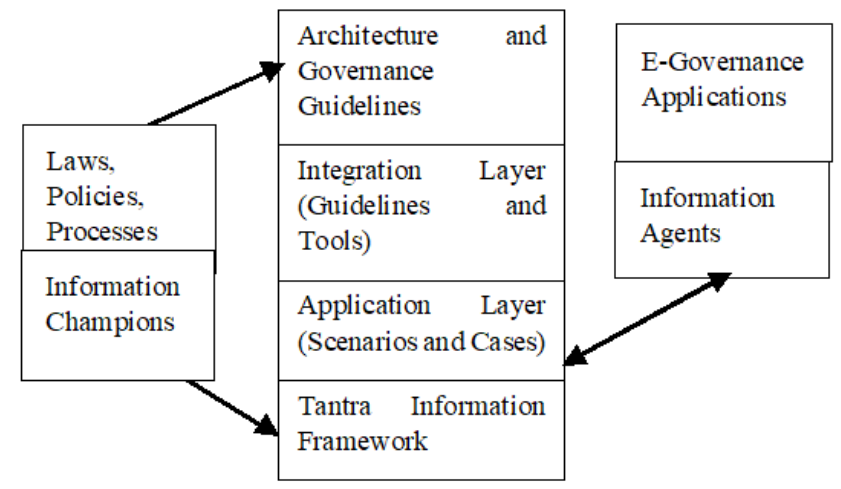

Figure 8. Tantra digital governance framework.

Here Governance layer addresses information governance. It lays down procedures for information sharing and service level agreements. Integration layer provides tools and guidelines for information agents to collaborate through applications at application layer. Information champions are personnel who feed information to Tantra framework as well as have access based on authorizations.

\section{Conclusions}

Balanced Growth theory was developed and critiqued by large number of Economists in 1950s. However, it is closely associated with Ragnar Nurkse who positioned the theory to eliminate vicious cycles of poverty in developing countries and put them on path to growth. For that he suggested a big push investment in multiple sectors that are complementary to each other. His assumption was that if we leave growth of economy in developing countries to individual entrepreneurs the results may be dismal. The same however may not apply to developed countries where waves of innovation uplifted economists. He considered productivity as key determinant of market growth. In this paper we have reimagined the balanced growth model and suggested that market equilibrium is more important than just ramping up supply, achieving sectoral balance using 5-sector model in place of 3-sector model, importance of anticipated profitability than just productivity and market size. In addition, we have discussed the challenges of improving wages and employment levels and reducing disparities within sectors. To achieve this mammoth task, we have proposed use of ontology-based Tantra Good Governance framework that models the entire social information as a multi-modal network. Tantra Framework inter-operates with Balanced Scorecard, Theory of Change and Theory of Separations. Tantra Framework provides a fine-grained way to keep track of economic, market and social indictors. Finally, Tantra information framework needs to evolve to Tantra Digital Governance Framework to manage and sustain the new paradigm. 


\section{References}

1. Acemoglu, Daron \& Robinson, James (2012). Why Nations Fail: The Origins of Power, Prosperity and Poverty, New York: Crown; 2012. https://doi.org/10.1355/ae29-2j.

2. Balakrishnan, Pulapre (2018), Architecture is not the force. The Hindu.

3. Bartels (1968). The General Theory of Marketing. The General of Marketing, 32(1), 29-33 https://doi. org/10.2307/1249193.

4. Bhatt, O.P. (1964). Theories of Balanced and Unbalanced Growth: A Critical Appraisal. Wiley Online Library, 17(4), 612-26. https://doi.org/10.1111/j.1467-6435.1964.tb01844.x.

5. Chancel, Lukas \& Piketty, Thomas (2017). Indian Income Inequality from British Raj to Billion Raj, WID. World Working Paper Series N²017/11, July 2017.

6. Clark, Colin (1940). Conditions of Economic Progress.

7. Debroy, Bibek (2018). Upside of scaling down, India must offer unique services, not just depend on low-cost production, Indian Express, December 13, 2018.

8. Economics Discussion, Theory of Balance Growth: Concept, Definition and Basics, http://www.economicsdiscussion.net/theories/theory-of-balance-growth-concept-definition-and-basis/4618.

9. Economics Online, Structural Change Theory, https:// www.economicsonline.co.uk/Global_economics/Structural_change_theory.html.

10. Fisher, Allan GB. (1939). Production, primary, secondary and tertiary. Economic Record, 15(1), 24-38. https://doi. org/10.1111/j.1475-4932.1939.tb01015.x.

11. Gomes, Ricardo Corrêa \& Lidde, Joyce (2009). The balanced scorecard as a performance management tool for third sector organizations: The case of the Arthur Bernardes foundation, Brazil. Brazilian Administration Review, 6(4), 2009. https://doi.org/10.1590/S1807-76922009000400006.

12. Hirschman, Albert (1958). Strategy of Economic Development, Yale.

13. Investopedia (2018). Development Economics. https://www. investopedia.com/terms/d/development-economics.asp.

14. Jaffelot, Christophe (2018). Farmers and others. Will the Kisan take care of interest of landless peasants as well? Indian Express, $7^{\text {th }}$ December 2018.

15. Kaplan, Robert (2010). Conceptual Foundations of the Balanced Scorecard, Working Paper. https://doi.org/10.2139/ ssrn. 1562586 .

16. Kindleberger, C.P. (1958). Economic Development, New York.

17. Lewis, W.A. (1955). The Theory of Economic Growth, London, Routeldge Library Editions.

18. Martin, Patricia Yancey \& Turner, Barry A. (1986). Grounded theory and organizational research. The Journal of Applied Behavioral Science, April 1986.

19. Myers, Michael David (June 1997). Qualitative Research in Information Systems, MIS Quarterly. https://doi. org/10.2307/249422.

20. Nurkse, R. (1953). Problems of Capital Formation in Underdeveloped Countries, Oxford Press.
21. Nurkse, Ragnar (1961). Equilibrium and Growth in the World Economy, Economic Essays, edited by Berler, Goitfriehd A, Harvard; 1961.

22. Prabhu, S.M., Murthy, K.N.B. \& Subramanyam, N. (2018b). Revenue capture using ontology-based tantra framework. International Journal of Management, Technology and Engineering, 8(12), 1479-89

23. Prabhu, S.M., Murthy, K.N.B. \& Subramanyam, N (2019b). Intelligent Social Banking using Tantra Framework, AICAI'19, Amity University, Dubai; February 4-6, 2019. https:// doi.org/10.1109/AICAI.2019.8701399.

24. Prabhu, S.M., Murthy, K.N.B. \& Subramanyam, N. (2018a). Knowledge management using ontology based Tantra framework for good governance. SRELS Journal of Information Management. 55(6), 299-308 http://www.srels.org/index.php/sjim/article/view/137988. https://doi.org/10.17821/ srels/2018/v55i6/137988

25. Prabhu, S.M., Murthy, K.N.B. \& Subramanyam, N. (2019a). Transforming India's electoral democracy using Tantra framework, CSIT. https://doi.org/10.1007/s40012-01900220-3.

26. Prabhu, S.M., Murthy, K.N.B. \& Subramanyam, N. (2019c). Balanced development using ontology based Tantra framework. SRELS Journal of Information Management, 56(1), 1-12, DOI: 10.17821/srels/2019/v56i1/139518. https://doi. org/10.17821/srels/2019/v56i1/139518.

27. Prabhu, S.M., Murthy, K.N.B. \& Subramanyam, N. (2019d). Validating Tantra Framework using Entropy. Soc. Netw. Anal. Min. 9, 18. https://doi.org/10.1007/s13278-019-0562-1.

28. Rodan, Rosenstein (1943). Problems of industrialization of Eastern and South-Eastern Europe. Economics Journal.

29. Sabharwal, Manish (2018a). India's job problem is easier to solve than its battle for wages. Hindustan Times.

30. Sabharwal, Manish (2018b). Problem is wages, not jobs. Answer lies in formalization, financialization. Indian Express.

31. Santos Jr, Paulo et al. (2013). An ontology-based analysis and semantics for organizational structure modelling in the ARIS method. Information Systems Journal.

32. Scitovsky, Tibor (1954). Two concepts of External Economies. Journal of Political Economy. https://doi. org/10.1086/257498.

33. Sheahan, John (1958), International specialization and the concept of balanced growth. The Quarterly Journal of Economics, 72(2), 183-97, Published by Oxford University Press. https://doi.org/10.2307/1880594.

34. Smith, Adam (1776). The Wealth of Nations, Bantam Classical Edition, 2003.

35. Tarafdar, Monideepa \& Singh, Ramendra (2011). A Market Separations Perspective to Analyze the Role of ICT in Development at the Bottom of the Pyramid", Proceedings of SIG GlobDev Fourth Annual Workshop, Shanghai, China.

36. The Wire, (2015). Economist Nobel Winner Angus Deaton has message for India. https://thewire.in/economy/economics-nobel-winner-angus-deaton-has-a-message-for-india.

37. TM Forum, Frameworx. https://www.tmforum.org/tm-forum-frameworx-2. 
38. Weiss (1995). Nothing as Practical as Good Theory: Exploring Theory-Based Evaluation for Comprehensive Community Initiatives for Children and Families, In: New' Approaches to Evaluating Community Initiatives, Concepts, Methods, and Contexts, Edited by Connell, Kubica and Schorr, The Aspen Institute. ISBN 0-89843-167-O.

39. Zachman, John A. (2003). Zachman Framework, A Primer for Enterprise Engineering and Manufacturing. Available at http://www.zachmaninternational.com.
40. Zachman, John A (2007). The Framework for Enterprise Architecture: Background, Description and Utility. https://www.zachman.com/resources/ea-articles-reference/327-the-framework-for-enterprise-architecture-background-description-and-utility-by-john-a-zachman. 